\title{
The Rights of Defendant in the Virtual Court Examination During Covid-19 Pandemic at Banda Aceh District Court
}

\author{
Suhaimi ${ }^{1,{ }^{*}}$ Roslaini Ramli ${ }^{1,}$ Enzus Tinianus ${ }^{1}$ \\ ${ }^{1}$ Faculty of Law, Syiah Kuala University, Banda Aceh, Indonesia \\ *Corresponding author. Email: pak_emy@unsyiah.ac.id
}

\begin{abstract}
A defendant is a person who is accused of having committed an is included in a criminal act based on the evidence obtained, which results in being examined and tried in court. The examination of criminal cases at all levels of examination is carried out in accordance with the Criminal Procedure Code (KUHAP). KUHAP has given legalization to the accused to defend his interests, especially in the process of examination at court proceedings, because this right is very risky in proving the defendant's guilt. However, with the outbreak of Corona Virus Disease 2019 (Covid-19) criminal case examinations have begun to be carried out online or virtually. It was feared that the trial was virtually neglected by the defendants' rights. This article attempts to answer the following questions: (1) Is the virtual court mechanism in line with the prevailing laws and regulations? (2) How was the implementation of the defendant's rights in a virtual trial during the Covid-19 Pandemic Era? According to the results of the research, the trial mechanism and the law of the procedure are still implemented according to the KUHAP. The trial process was the same as regulated in KUHAP, except that the defendant remained in the Detention Center (Rutan). This is to protect the community in preventing the spread of Covid-19. The rights of the defendant at trial must be maximally fulfilled. No rights of the defendant are neglected because the judge still follows the procedure as regulated in the KUHAP. In implementing the rights of the defendant, it relies fully on the role of the Legal Counsel, because it is the Legal Counsel who will fight for the rights of the defendant in court.
\end{abstract}

Keywords: defendant right, virtual trial, covid-19.

\section{INTRODUCTION}

A defendant is a person who is accused of having committed an act that is included in a criminal act based on the evidence obtained, which results in being examined and tried in court. According to JTC. Simorangkir, "the defendant is someone who has sufficient grounds to be examined before a court session, because the person is suspected of having committed a crime".[1]

Examination of criminal cases before court proceedings, are all carried out in accordance with Law No. 8 of 1981 concerning Criminal Procedure Law which is referred to as the Criminal Procedure Code (KUHAP). According to Article 1 point 15 of the KUHAP, what is meant by a defendant is a suspect who is prosecuted, examined, and tried in a court session.
The KUHAP, which came into effect on December 31, 1981, replaced the Het Herziene Inlandsch Reglement (HIR) which was a great gift for the Indonesian people. It "was intended to improve past judicial practices that were inconsistent with or against Human Rights (HAM). Thus, the KUHAP has provided human rights legalization to the accused to defend his interests in the legal process, including the examination process in court".[2]

The rights of a defendant in the process of examination in court as stipulated in the KUHAP include: The right to be informed in a language the defendant understands about what he is accused of; The right to provide information freely; The right to give an opinion on the testimony given by the witness; The right to ask questions to witnesses through the mediation of the head judge at trial; 
The right to test the truth of the testimony of witnesses; The right to file a defense of criminal charges; The right to be told all things about the witness's testimony, in the event that the judge asks

Defendants are given a set of rights stipulated in the KUHAP, in accordance with the objectives of the KUHAP to provide justice and protection of human rights in balance with the public interest, including for someone who is made a defendant. Some of the rights of the defendant as mentioned above are very risky rights in proving the defendant's guilt, so these rights are very important to be implemented in the case examination at court proceedings. However, following the global outbreak of Corona Virus Disease 2019 (Covid-19), Indonesia, through Presidential Decree No. 12 of 2020 On April 13, 2020, has designated Covid-19 as a Non-Natural National Disaster. Since then, criminal case investigations began to be carried out virtually via teleconference.

In virtual criminal case examination, the defendant is not attending the court physically, but is present at a detention center (RUTAN) and participates in the trial via teleconference. It is feared that the fulfillment of the defendant's rights will be neglected, especially since the legal adviser cannot directly accompany the defendant during the trial. Therefore it is necessary to conduct a study to determine the fulfillment of the rights of the defendant during the Covid-19 Pandemic, where the trial is conducted virtually.

Thus the problem can be formulated as follows:

1. Is the virtual court mechanism in accordance with the prevailing laws and regulations?

2. How was the implementation of the defendant's rights in a virtual trial during the Covid-19 Pandemic Era?

Based on the background and problem formulation above, the research objectives are:

1. To find out and disclose the implementation of criminal proceedings during the Covid-19 Pandemic Era in relation to the applicable laws and regulations.

2. To know and reveal the implementation of the defendant's rights in a virtual trial during the Covid-19 Pandemic Era.

Based on the literature review, it is was found that some research had investigated relevant topic to this study, among others are;

1. Building a Legal Culture in Virtual Trials (Study on the Development of Criminal Sessions via Teleconference, by Dewi Rahmaningsih Nogroho and Suteki, of 2020. for certain information from the witness without the defendant being present; The right not to answer or to refuse to answer questions posed to him; and The right to show evidence.

The purpose of this research is "to explore and understand the development of teleconferencing trials within the Public Prosecutor's Office of Semarang City and build a virtual trial culture in the future".[3] The results of this study include: "virtual trials still leave several problems classified into juridical-procedural, juridical-substantial, and technical-empirical problems. In the context of legal culture, among the three factors that are currently crucial to be considered are technical-empirical issues, the components of non-legal factors in the form of human resources, the availability of facilities and infrastructure, and decision habits which are proven to affect the operation of law at a concrete level. Therefore, what must be addressed to welcome virtual trials in the future is to prepare a legal culture in addition to preparing the structure and substance of the law ". [3]

This research is different from Nogroho and Suteki's research, because Nogroho and Suteki's did not address the issue of fulfilling the rights of the defendant in a virtual trial.

2. A study by Lumbanraja examines the development of the implementation and development of online court regulations implemented in Indonesia and compares them to Virtual Civil Courts in the United States.[4] The results of this study indicate that "The practice of Virtual Courts in the United States, which has long been applied, has developed significantly. Courts in various states of the United States use virtual video conferencing method which through the Zoom platform. The application of Virtual Courts is regulated and limited in the CARES Act which came into effect on March 27, 2020. The issue of Virtual Courts regulation in the United States arises from the question of whether Virtual Courts as regulated in state court regulations (Federal Rule) conflict with Supreme Court regulations (Supreme Court). This needs to be answered, by amending the regulations at the Supreme Court level because they are more flexible and have a wider jurisdiction ". [4]

Judging from the objectives and results of the above research, the present study is a different compared to the 2 (two) studies above. 


\section{RESEARCH METHOD}

This research is an empirical juridical study that analyzes "the implementation of normative law in any particular legal event that occurs in society".[5] The data were obtained through field research based on interviews and field observations. Of the several trials that were taking place at the Banda Aceh District Court, only a few trials were currently in the process of examining the accused. Furthermore, conducted a direct interview with the Chairman of the Banda Aceh District Court who was also a judge at the court, Public Prosecutors at the Banda Aceh District Attorney, and Legal Counsel in Banda Aceh City. The respondents selected were respondents who handled criminal cases during the Covid-19 Pandemic, whose trials were conducted virtually. Meanwhile, observations were made by directly observing the implementation of the criminal case examinations at the Banda Aceh District Court, which was conducted virtually. The collected data were then sorted systematically and described descriptively to achieve the goals.

\section{FINDINGS AND DISCUSSION}

Two issues will be discussed in this research, namely:

\subsection{The Mechanism For The Trial Of Criminal In The Era Of Pandemic Covid-19}

Article 8 paragraph (1) of Law No. 48 of 2009 concerning Judicial Power affirms that every person who is suspected, arrested, detained, prosecuted, or brought before a court must be presumed innocent before a court ruling declares his guilt and has obtained permanent legal force. This provision is known as the presumption of innocence, which means that a person who is undergoing a (criminal) case process must be considered innocent until a court decision is legally enforceable.

The consequence of this principle is that a person who is made a defendant in a court session is not necessarily guilty or proven to be the perpetrator of a criminal act. So, according to Article 191 paragraph (1) and (2) KUHAP, "there is the possibility of being acquitted (vrijspraak) or acquitted of all legal charges (ontslag van alle rechtsvervolging)". The defendant's guilt truly depends on the results of the examination in court. The judge will release the defendant if the evidence obtained at trial is not sufficient to prove the defendant's guilt, because the judge does not have confidence in the defendant's guilt so that the act which was accused of the defendant was not proven legally and convincingly.[6]
The examination in court is very important to reveal the guilt of the accused against the act he is accused of, because everything will be revealed in front of the trial. However, with the outbreak of Covid-19, criminal case investigations began to be carried out online or virtually via teleconference. At the same time, on the same date, the Supreme Court has signed a Memorandum of Understanding (MoU) with the Attorney General's Office and the Ministry of Law and Human Rights, in this particular case the Directorate General of Corrections, which regulates the implementation of criminal proceedings through video conferences. The MoU is specifically for criminal cases and is valid until the government revokes the emergency status of the Covid-19 outbreak and can also be extended if needed. The cooperation agreement is stated in a joint decree dated April 13, 2020 No. 402 / DJU / KM.01.1 / 4/2020; KEP-17 / E / Ejp / 04/2020; PAS-08.HH.05.05 Year 2020 concerning the Implementation of Trials by Teleconference. The Supreme Court has also issued Supreme Mahmakah Regulation (PERMA) No. 4 of 2020 concerning the Administration and Trial of Criminal Cases Electronically.

The implementation of case examination in court (trial) which is conducted electronically (virtual) by using the Teleconference facility raises pros and cons in society, including:

1. "Conducting an electronic trial is considered a progressive step in solving the problem of case stagnation due to the spread of Covid-19. Various kinds of praise were raised, as if judging that law enforcers were able to innovate, to keep the trial process running. However, it turns out that it has encountered obstacles, especially in matters of evidence at trial. Whereas proof is the most important right in the judiciary to prove the guilt of the accused, judges are also obliged to seek material truth".[7]

2. "The Secretary-General of the National Leadership Council of the Indonesian Advocates Association (Peradi) criticized the online trial for criminal cases. Criminal cases may not be heard by teleconference. In addition to violating the rules regarding trial procedures stipulated in the KUHAP, the implementation of such online trials is very susceptible to being mocked or cannot be legally accounted for. Because, the process of virtual criminal proceedings violate the rules and laws. As it is not stated in the KUHAP".[8]

3. "The Ombudsman of the Republic of Indonesia discovered the potential for 
maladministration related to the holding of online trials during the Covid-19 pandemic. There are 2 (two) types of maladministration according to the law, namely maladministration relating to prolonged delays and maladministration related to incompetence".[9]

4. "Member of Commission III DPR RI from the PDIP faction, Junimart Girsang, explained that virtual criminal proceedings violate the rules and laws. As it is not stated in the KUHAP, virtual criminal court proceedings are not allowed and against the rules".[10]

Regardless of the above criticism, "the trial is virtually forced to be held, because this is a form of concern for prioritizing public safety. The trial mechanism is carried out similar to an ordinary trial (offline). The procedural law is still applied, where only the defendant is absent from the court room, while judges, prosecutors, legal advisors, and witnesses remain in attendance. The legal advisor should have been at the detention center accompanying the defendant, but because of Covid19 , legal advisers were not allowed to accompany the defendant at the detention center. This is to maintain public safety in preventing the spread of Covid-19, not for the "an sich" interest of the agency concerned. If the defendant in the detention center goes in and out, this becomes a space for the spread of Covid-19".[11]

According to Ramli Husen, "the defendant remains in the detention center (not presented to court) and the legal counsel is not allowed to accompany the defendant in the detention center. Alternatively, the defendant is brought to court and accompanied by a legal advisor. This is solely to prevent the transmission of Covid-19 for hundreds of people in detention centers, both prisoners (defendants) and prison employees or officers (wardens)".[12]

Maurizal further said that: "In preventing the spread of Covid-19, due to certain circumstances, the Public Prosecutor is not allowed to appear in court, but must be at the District Prosecutor's Office and not at home. In principle, everything must be in the courtroom, except for the defendant who is allowed from the detention center and his legal counsel to be in court accompanying the defendant indirectly. The defendant attended the trial from the detention center through video conference facilities, because the detention center should also provide a separate room with video conference facilities".[13]

Furthermore, Ainal Mardhiah, a Judge and also as Chairperson of the Banda Aceh District Court, said that: "The smooth running of the trial is also largely determined by the facilities or means available. In this case, the Banda Aceh District Court, a few months after the trial, virtually only had 1 (one) unit of teleconference facility, but recently it has added 1 (one) more unit so that now it has become 2 (two). Of course you can imagine how difficult it would be to hold a virtual trial with only 1 (one) unit of facilities, compared to the tight schedule for the trial to be held. Coupled with the internet network whose signal is not good and the condition of the electricity network in the city of Banda Aceh which is suddenly cut off. This is an obstacle that greatly affects the smooth running of the trial virtually. However, the rights of the defendant were still prioritized, despite all the limitations".[11]

Based on the description above, it can be understood that trials of criminal cases during the Covid-19 pandemic were carried out virtually, which was intended to protect the public. However, the trial mechanism is still implemented in accordance with the applicable laws and regulations (KUHAP).

\subsection{The Implementation The Rights Of Defendant In Virtual Trials In The Era Of The Covid-19 Pandemic}

Regarding the implementation of virtual trials, Ainal Mardhiah said that: "The first virtual trial was held at the Banda Aceh District Court on March 30, 2020. The virtual trial was connected directly from the Banda Aceh District Court, Detention Center, and the District Prosecutor's Office. This was done because the defendant was not allowed to be taken outside of the detention center to attend the trial, due to the outbreak of Covid-19. However, the rights of the defendant in court proceedings must be maximally fulfilled, no rights of the defendant are neglected, because the judge still follows the procedure as regulated in the KUHAP. If the defendant did not understand, about what the judge was asking because of the problem with the internet network, the judge would repeat the question again and sometimes this had to be repeated several times until the defendant understood it".[11]

Meanwhile, Maurizal, as the Prosecutor (Public Prosecutor at the Banda Aceh District Attorney), said that: "Sometimes the defendant was impolite. In answering the judge's question, defendant's tone seemed to make fun of the judge and this happened because of the psychological factor. In normal circumstances where the defendant is presented to the trial, psychological pressure of being in the courtroom prevents this from happening. In the courtroom, defendants usually look down, answer questions politely, turn or look at the faces of 
judges and the public prosecutor. In a virtual trial, where the judge and the public prosecutor do not face the defendant directly, the defendant might behave or answer questions with impolite words. If this happens and the defendant's rights are neglected, it can be said that the defendant's rights were neglected because of the defendant's improper behavior".[13]

According to Januar Barus, "in fact, the role of the Legal Counsel is very crucial in implementing the rights of the defendant in virtual court proceedings, because the Legal Counsel must really hear clearly what is being asked by the judge, by the public prosecutor and the content of the expert's statement and the answer from the defendant. If the defendant is not serious about attending the trial because the defendant is not dealing directly with the judge and the public prosecutor, the Legal Counsel can correct it and remind the defendant to be serious and focus on attending the trial so that will not harm the defendant himself.[14]

Furthermore, Ramli Husen added that: "An incident like the one mentioned above has been experienced by a Legal Counsel when handling a narcotics crime case. At that time the judge asked whether defendant was involved in distributing narcotics, and at that time the condition of the internet network was unstable, causing the judge's voice to be unclearly heard. The defendant, who was less serious in attending the virtual trial (because he was not in court), answered yes or justified the Judge's question. The Legal Advisor who heard the Defendant's answer immediately reconfirmed the defendant's answer and asked the judge to repeat the question to defendant because the internet network was not stable. Finally, the defendant explained that he was not involved in distributing narcotics, but only for his own use".[12]

"This is also the case when the judge shows and asks about the evidence used in the criminal act. In this case, the defendant could not see clearly because it was shown remotely via video conference. If the Defendant is not accompanied by a Legal Counsel, then the defendant's rights will be neglected, because evidence cannot be checked carefully by the defendant".[14] It is different if the Defendant is accompanied by a Legal Counsel, who will later assist the Defendant in identifying and examining the evidence presented in the case.

Furthermore, Januar Barus added that: "If the Defendant did not dare to confront the testimony given by the witness, some of his rights would be lost. Moreover, when the trial is conducted virtually, it is difficult for the defendant to refute the witness's testimony".[14] In case the defendant is accompanied by a Legal Counsel, the Legal Counsel will rectify unclear matters, so that it can be said that the fulfillment of the Defendant's rights will be assisted by his Legal Counsel.

Thus, implementing the rights of the defendant in a virtual court mainly depends on the role of the Legal Counsel, who will fight for the rights of the defendant in court

\section{CONCLUSION}

With the stipulation of Covid-19 as a NonNatural Disaster and the signing of the MoU by the Supreme Court with the Attorney General's Office and the Ministry of Law and Human Rights, criminal proceedings during the Covid-19 pandemic were carried out virtually. The trial mechanism and the law of the procedure will still be implemented in accordance with the applicable laws and regulations (KUHAP), but the defendant remains in the detention center and is not allowed to be brought to court. This is to protect the community from the spread of Covid- 19 .

The rights of the defendant during examination in court proceedings are still virtually fulfilled and implemented, and none of them is neglected. In this case the judge still follows the procedure as stipulated in the Criminal Procedure Code. Apart from that, implementing the rights of the defendant truly depends on the role of the Legal Counsel, because the Legal Counsel will fight for the rights of the defendant in court.

Considering the large role of legal counsel in implementing the rights of defendants in courts where the trial is conducted virtually, it is hoped that the government will provide free legal counsel to all incapacitated defendants who are accused of committing a crime. In this case, it is not only limited to defendants who are threatened with a sentence of five years or more as stipulated in Article 56 of the KUHAP, but also defendants whose sentence is under five years.

\section{REFERENCES}

[1] D. Prints, Hukum Acara Pidana Dalam Praktik. Jakarta: Djambatan, 1998.

[2] A. S. Nganro, "Praktek Peneraapan KUHAP dan Perlindungan HAM," hukumonline.com, 2006. https://www.hukumonline.com/berita/baca/ hol15621/praktik-penerapan-kuhap-danperlindungan- $/$. 
[3] D. R. N. Suteki, "Membangun Budaya Hukum Persidangan Virtual (Studi Perkembangan Sidang Tindak Pidana via Telekonferensi," Pembang. Huk. Indones., vol. 2, no. 3, p. 294, 2020, [Online]. Available: https://ejournal2.undip.ac.id/index.php/jphi/ article/view/8799/4507.

[4] A. D. Lumbanraja, "Perkembangan Regulasi Dan Pelaksanaan Persidangan Online Di Indonesia Dan Amerika Serikat Selama Pandemi Covid-19," Crepido, vol. 2, no. 1, pp. 46-58, 2020, [Online]. Available:

https://ejournal2.undip.ac.id/index.php/crep ido/article/view/7896/4046.

[5] A. Muhammad, Hukum dan Penelitian Hukum. Bandung: Citra Aditya Bakti, 2004.

[6] M. Y. Harahap, Pembahasan Permasalahan dan Penerapan KUHAP. Jakarta: Sinar Grafika, 2003.

[7] Suara.com, "No Title," Suara.com, 2020. https://www.suara.com/yoursay/2020/05/22 /163836/keabsahan-pembuktian-dalampersidangan-online-di-masa-pandemicovid-19.

[8] "No Title." https://www.ayojakarta.com/read/2020/04/0 1/ 14565/ma-dan-kejagung-dikecamlegalkan-sidang-virtual,.

[9] Kompas.com, “Ombudsman Temukan Potensi Maladministrasi Terkait Persidangan Online," Kompas.com, 2020. https://nasional.kompas.com/read/2020/06/ 09/16590321/ombudsman-temukanpotensi-maladministrasi-terkaitpersidangan-online?page=all\#page 2 .

[10] "Sidang Virtual Melanggar KUHAP." https://www.askara.co/read/2020/09/21/910 7/ sidang-virtual-melanggar-kuhap.

[11] A. Mardhiah, "Interview," Chairperson of the Banda Aceh District Court, October 5, 2020.

[12] Ramli Husen, "Interview," Senior Advocate (Legal Advisor) in Banda Aceh, September 8, 2020.

[13] Maurizal, "Interview," Prosecutor (Public Prosecutor) at the Banda Aceh District Attorney, September 29, 2020.
[14] J. Barus, "Interview," Senior Advocate (Legal Advisor) in Banda Aceh, September $11,2020$. 